\title{
Effect of isotretinoin on periodontal tissues and oxidative stress markers in the saliva
}

\section{Izotretinoinin periodontal dokular ve tükürükteki oksidatif stres belirteçleri üzerine etkisi}

\section{Gülbahar Ustaoğlu, ๑ Șevki Güler, ๑ Mualla Polat*}

Bolu Abant İzzet Baysal University Faculty of Dentistry, Department of Periodontology, Bolu, Turkey

*Bolu Abant İzzet Baysal University Faculty of Medicine, Department of Dermatology, Bolu, Turkey

\begin{abstract}
Background and Design: Isotretinoin is a vitamin A isomer, and is the most commonly used drug for the treatment and for achieving remission in severe acne. This study aimed to evaluate the effects of isotretinoin on periodontal tissues by assessing the clinical periodontal parameters and salivary oxidative stress (OS) markers.

Materials and Methods: Twenty-five patients (17 women and 8 men) aged between 20 to 25 years old, who were identified as candidates for the treatment of acne with isotretinoin; and 18 healthy volunteers (14 women and 4 men), who were age- and sex-matched with the patients, and who did not have any inflammatory skin diseases or periodontal diseases, were included in the study. Patients received isotretinoin after their clinical periodontal parameters were recorded and saliva was collected at the baseline. Clinical periodontal parameters and salivary oxidative biomarkers were evaluated before and after 6 months of isotretinoin treatment.

Results: The baseline periodontal clinical parameters and salivary biomarkers were not statistically different between groups ( $p>0.05)$. The total antioxidant capacity (TAC) values of the patient group were found out to be statistically decreased in the sixth month compared to the baseline $(p=0.001)$.

Conclusion: The study demonstrated that the use of isotretinoin due to acne vulgaris did not create significant changes in the periodontal tissues, but caused a significant decrease in the TAC levels. These alterations in the OS regulation may potentially take part in the pathological mechanisms involved in the emergence of isotretinoin's adverse effects.
\end{abstract}

Keywords: Acne vulgaris, isotretinoin, oxidative stress, periodontal diseases

Öz

Amaç: İzotretinoin bir A vitamini izomeridir ve şiddetli aknenin tedavisi için ve remisyon elde etmek için en sık kullanılan ilaçtır. Bu çalısmada, klinik periodontal parametreler ve tükürük oksidatif stres (OS) belirteçleri ile, izotretinoinin periodontal dokular üzerindeki etkilerinin değerlendirilmesi amaçlandı.

Gereç ve Yöntem: Çalışmaya yaşları 20 ila 25 arasında değişen, akne tedavisi için izotretinoin alması belirlenen yirmi beş hasta (17 kadın ve 8 erkek) ve cinsiyet, yaş ortalamaları ile eşleştirilen, enflamatuvar deri hastalıkları veya periodontal hastalıkları olmayan 18 sağ ıklı gönüllü (14 kadın ve 4 erkek) dahil edildi. Hastalar başlangıç klinik periodontal parametreleri kaydedildikten ve tükürük örnekleri toplandıktan sonra izotretinoin aldı. Klinik periodontal parametreler ve tükürük oksidatif biyobelirteçler 6 aylık izotretinoin tedavisinden önce ve sonra değerlendirildi. Bulgular: Başlangıç periodontal klinik parametreleri ve tükürük biyobelirteçleri arasında gruplar arasında istatistiksel olarak farklılık bulunmadı $(p>0,05)$. Hasta grubunun total antioksidan kapasite (TAK) değerlerinin altıncı ayda başlangıç değerlerine göre istatistiksel olarak azaldığı bulundu $(p=0,001)$.

Sonuç: Çalışma, akne vulgaris nedeniyle izotretinoin kullanımının periodontal dokularda önemli değişiklikler yaratmadığını, ancak TAK seviyelerinde anlamlı bir düşüşe neden olduğunu göstermiştir. OS düzenlemesindeki bu değişiklikler potansiyel olarak, izotretinoinin olumsuz etkilerinin ortaya çıkmasında rol oynayan patolojik mekanizmalarda yer alabilir.

Anahtar Kelimeler: Akne vulgaris, izotretinoin, oksidatif stres, periodontal hastalıklar

Address for Correspondence/Yazışma Adresi: Gülbahar Ustaoğlu MD, Bolu Abant İzzet Baysal University Faculty of Dentistry, Department of Periodontology, Bolu, Turkey Phone: +90 5445675166 E-mail: gulbaharustaoglu@hotmail.com Received/Geliş Tarihi: 22.11.2019 Accepted/Kabul Tarihi: 18.05.2020 ORCID: orcid.org/0000-0002-4205-861X

(c) Copyright 2020 by Turkish Society of Dermatology and Venereology

Turkderm - Turkish Archives of Dermatology and Venereology published by Galenos Yayınevi. 


\section{Introduction}

Acne vulgaris, a chronic inflammatory disease, is the most frequently diagnosed dermatosis with a lifetime prevalence of approximately $85 \%$. The disease occurs most commonly during adolescence ${ }^{1}$. Isotretinoin is a vitamin $A$ isomer and is the most commonly used drug for the treatment and for achieving remission in persistent severe acne ${ }^{2,3}$. The conventional treatment with isotretinoin is administered at a dose of $0.5-1.0 \mathrm{mg} / \mathrm{kg} /$ day for 20 weeks in patients suffering from acne $\mathrm{C}^{4}$. The occurrence of adverse effects in association with the isotretinoin treatment is dose-dependent and these effects share similarities to those observed with other oral retinoids.

In the literature, it has been reported in adults and children that alterations occur in bone ossification, along with progressive calcification of ligaments and tendons (osteoporosis or ectopic ossification and hyperostosis), in association with high-dose and longterm isotretinoin therapy ${ }^{5,6}$. Moreover, there are studies available in the literature, demonstrating that vitamin A intake induces oxidative stress (OS) at the cellular level, concluding that OS may be a major factor in the emergence of side effects related to isotretinoin ${ }^{7-9}$. It has been reported that; based on the increased load of oxidants and the resulting insufficient antioxidative efforts, OS develops and has been suggested taking part potentially in the etiopathogenesis of several pathological conditions, including the periodontal disease, too ${ }^{10}$, which is a common and important public health problem. The characteristic manifestation of the disease, the periodontal destruction, results from an interplay of multiple mechanisms including lipid peroxidation, denaturation of proteins, oxidation of key enzymes, and injuries in the architecture of DNA/RNA ${ }^{11}$.

Clinical parameters of periodontal disease; including pocket depth probing, quantification of bleeding on probing (BOP), and the clinically assessed extent of attachment loss are of limited value since they reveal information for the retrospective disease activity rather than allowing to evaluate the disease activity at present ${ }^{12}$. Aiming to meet the needs in this field, salivary markers have been proposed as promising tools in investigating the relationships of oral diseases, OS, and antioxidant status $^{13}$. Previous studies have reported that OS plays an important role in the pathology of periodontal disease, and an increase in OS negatively affects the clinical periodontal condition ${ }^{14-17}$

Although there are several studies, which reported the side effects of isotretinoin on various organs and tissues ${ }^{18-20}$; as far as we observed, there are no studies about the effects of isotretinoin on periodontal tissues. With this present study, we aimed to determine the effects of isotretinoin on the periodontal tissue by assessing the clinical periodontal parameters and OS markers in the saliva.

\section{Materials and Methods}

This prospective study was conducted in the period from November 2017 to May 2018 after receiving the approval of the Clinical Research Ethics Committee of Bolu Abant İzet Baysal University (approval number: 2017/85). Based on a previous study ${ }^{21}$, a power calculation was performed, and the sample size was determined ( $\mathrm{G}^{*}$ Power 3.1 software; Heinrich Heine University, Dusseldorf, Germany). A total of 25 patients (17 women and 8 men) aged 20-25 years were included, who were identified as candidates to receive isotretinoin for the treatment of acne during six months. The study was completed with 18 patients with acne vulgaris, who received isotretinoin; because 7 patients moved to another city and discontinued the treatment. Apart from the 25 patients included in the study, 18 healthy participants (14 women and 4 men) were included in the study, too, to form a control group. These healthy participants did not have any inflammatory skin diseases, and their mean age and sex were matched with those of the individuals in the patient group. Also, healthy participants were included in the study if they had no radiographically detected bone loss and if they had no sites with clinical attachment loss and no sites with probing depth (PD) of $>3 \mathrm{~mm}$ in their oral cavity. Before being enrolled in the study, the participants provided their consents by signing the informed consent forms, printed on paper. The study was conducted in compliance with ethical standards in compliance with the current version of the Declaration of Helsinki.

The study was carried out in autumn and winter to minimize the emergence of isotretinoin side effects. All participants volunteered to be included in the study. Isotretinoin was administered to the patients at a dose of 0.5-0.7 mg/ $\mathrm{kg}$. Participants received isotretinoin after their clinical periodontal parameters were recorded and their saliva was collected at baseline.

Volunteering individuals with pregnancy, lactation, hyperlipidemia, liver or renal dysfunction, systemic diseases such as diabetes, atherosclerotic heart disease, thyroid disease, anemia, or metabolic diseases were excluded from the study.

\section{Clinical examination}

All clinical periodontal parameters including the plaque index $(\mathrm{PI})^{22}$, gingival index $(\mathrm{GI})^{23}, \mathrm{BOP}, \mathrm{PD}$, and clinical attachment level $(\mathrm{CAL})$ were evaluated at baseline before starting isotretinoin treatment and after 6 months at the end of the study. The examinations were performed by one experienced periodontist (G.U.) and a calibration exercise was performed to obtain acceptable intraexaminer reproducibility. Periodontal examinations were performed with a Williams probe (Hu-Friedy, Chicago, IL, USA). The clinical parameters of PD and CAL were measured for every tooth present in the oral cavity (Figure 1). The measurements were performed at a total of six sites, which were the distolingual, midlingual, mesiolingual, distobuccal, midbuccal,

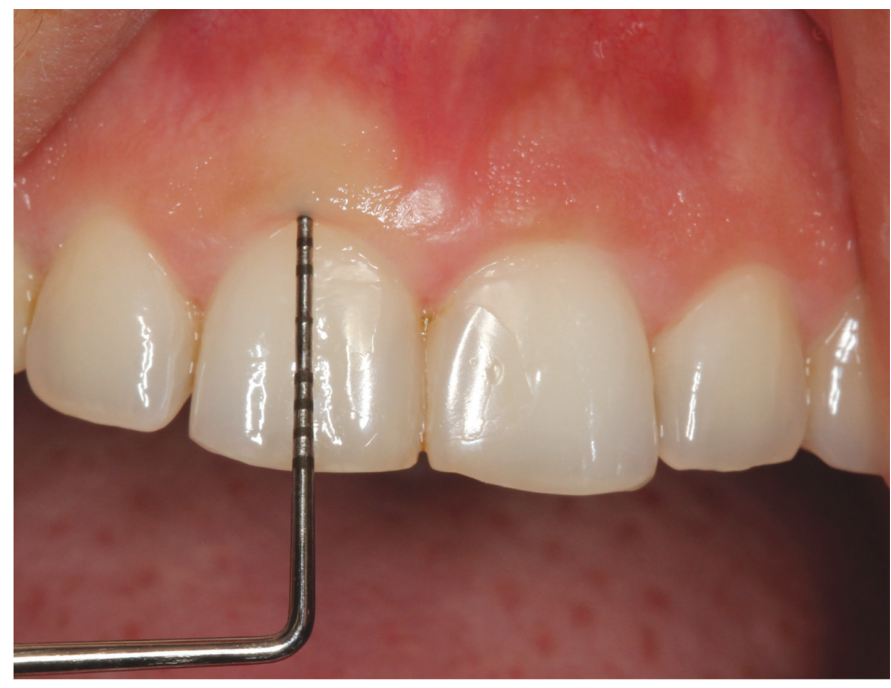

Figure 1. Measurement of probing depth with a Williams probe 
and mesiobuccal regions. The obtained results were recorded in approximation to the nearest whole millimeter. The distance from the bottom of the pocket to the cementoenamel junction was defined as CAL and this distance between these two points was measured and recorded. To calculate the mean values of $P D$ and $C A L$, the total score obtained from all teeth were divided by the total number of teeth examined during the study. After the periodontal examinations, oral hygiene motivation was promoted only but no periodontal treatment was provided for the participants.

\section{Silness and Loe Plaque index ${ }^{22}$}

Score 0: Absence of microbial plaque; score 1: Thin film of microbial plaque along the free gingival margin; score 2: Moderate accumulation with plaque in the sulcus; score 3: Large amount of plaque in sulcus or pocket along the free gingival margin.

\section{Loe and Silness Gingival index ${ }^{23}$}

Score 0: Normal gingiva; score 1: Mild inflammation - slight change in color, slight edema. No BOP; score 2: Moderate inflammation - redness, edema, glazing. BOP; score 3: Severe inflammation - marked redness and edema, ulceration. Tendency toward spontaneous bleeding.

\section{Saliva samples}

OS biomarkers including total antioxidant capacity (TAC), total oxidant status (TOS), and oxidative stress index (OSI) were assessed along with some routine biochemical constituents at baseline (pre-treatment) and in the sixth month of isotretinoin treatment (post-treatment). Saliva samples of approximately $2 \mathrm{~mL}$ were collected from the study participants from 09:00 to 12:00 a.m., eight hours before food intake, while the individuals were present in a quiet room during the clinical examination. The whole saliva samples were centrifuged at 1,000 $\mathrm{g}$ for 10 minutes to remove cell debris immediately after they were collected in disposable tubes. After the centrifugation, the supernatant was transferred to small aliquots to be stored at $-80^{\circ} \mathrm{C}$ until the time of analysis.

\section{Total antioxidant capacity}

Using commercially available kits (Relassay, Turkey), TAC levels were measured with a recently introduced automated method. The method is based on the bleaching activity of antioxidants on the radical cation, ABTS [2,2'-Azino-bis (3-ethylbenzothiazoline-6-sulfonic acid)], which is a stable compound with a characteristic color. It has been reported that this method provides precision values below 3\%, which are accepted as excellent. The results obtained in our study were expressed as $\mathrm{mmol}$ Trolox equivalent/ $\mathrm{L}^{24}$.

\section{Total oxidant status}

TOS levels were determined with a new method, which operates via the oxidation activity of oxidant molecules in the sample. For this purpose, commercially available kits (Relassay, Turkey) were used. This method is principally based on the activity of oxidants in the sample, oxidizing the ferrous ion-o-dianisidine complex to ferric ion. In our study, the oxidation reaction was facilitated by glycerol molecules available in the reaction medium. A colored complex was the yield of the combination of the ferric ion and xylenol orange in the acidic medium. The color intensity was measured by spectrophotometry, indicating the number of oxidant molecules in the sample. This result was calibrated with hydrogen peroxide. The obtained results in this test were expressed as micromolar hydrogen peroxide equivalent per liter ( $\mu \mathrm{mol} \mathrm{H}_{2} \mathrm{O}_{2}$ equivalent/L) ${ }^{25}$.

\section{Oxidative stress index}

In this study, we used the ratio of TOS to TAS to find out the OSI. First, the unit of the obtained TAS value was converted to $\mu \mathrm{mol} / \mathrm{L}$ for calculation purposes; then, OSI was calculated using the formula below:

OSI (arbitrary unit): TOS ( $\mu$ mol $\mathrm{H}_{2} \mathrm{O}_{2}$ equivalent/L)/TAC ( $\mu$ mol Trolox equivalent/L) ${ }^{26,27}$.

\section{Statistical Analysis}

We used the Kolmogorov-Smirnov test to evaluate whether the obtained data in this study conformed to a normal distribution. The independent Sample t-test or the Mann-Whitney $U$ test was used for analyzing whether any statistical significances existed between groups of the variables at baseline. The chi-square test was used for finding gender differences between the study groups. Intragroup comparisons were performed using the paired t-test or the Wilcoxon signed-rank test. Bivariate Pearson correlation was used for determining the relationships between the variables. A p-value of $<0.05$ was accepted to indicate statistical significance.

\section{Results}

There were no statistically significant differences in age and gender between the patient and the control groups ( $p>0.05)$. The mean age was $22.46 \pm 1.50$ years in the patient group and $22.66 \pm 1.58$ years in the control group.

Compared to baseline; the periodontal clinical parameters (PD, BOP, $\mathrm{CAL}, \mathrm{PI}$, and $\mathrm{GI}$ index) and salivary biomarkers were not statistically different between the study groups ( $p>0.05$ ) (Table 1).

Table 2 presents the values of the variables at baseline and after isotretinoin treatment in the patient group. A statistically significant reduction was found in the TAC values in the sixth month compared to baseline $(p=0.001)$.

\begin{tabular}{|c|c|c|c|}
\hline Parameters & $\begin{array}{l}\text { Test group }(n=18) \\
\text { mean } \pm S D \text { or } \\
\text { median } \\
\text { (minimum- } \\
\text { maximum) }\end{array}$ & $\begin{array}{l}\text { Control group } \\
(n=18) \text { mean } \pm \text { SD or } \\
\text { median } \\
\text { (minimum- } \\
\text { maximum) }\end{array}$ & p \\
\hline PD & $1.66 \pm 0.38$ & $1.51 \pm 0.47$ & 0.343 \\
\hline CAL & $1.66 \pm 0.38$ & $1.51 \pm 0.47$ & 0.343 \\
\hline $\mathrm{Pl}$ & $1.15 \pm 0.74$ & $1.18 \pm 0.31$ & 0.866 \\
\hline Gl & $1.04 \pm 0.55$ & $0.98 \pm 0.36$ & 0.737 \\
\hline BOP & $42.85(0-100)$ & $40.20(0-100)$ & 0.649 \\
\hline TAC & $0.74 \pm 0.30$ & $0.75 \pm 0.54$ & 0.948 \\
\hline TOS & $14.65 \pm 9.10$ & $13.90 \pm 8$ & 0.811 \\
\hline OSI & $1.90 \pm 0.84$ & $2.47 \pm 2.03$ & 0.330 \\
\hline
\end{tabular}


In all study participants, it was investigated whether any correlations existed between the clinical parameters and the TOS, TAC, and OSI values (Table 3). A significantly positive correlation was observed

\section{Table 2. Comparisons of clinical periodontal and salivary} oxidative stress parameters according to baseline

\begin{tabular}{|c|c|c|}
\hline Parameters & $\begin{array}{l}\text { Test group }(n=18) \\
\text { mean } \pm \text { SD or median } \\
\text { (minumum-maximum) }\end{array}$ & $\mathbf{p}$ \\
\hline PD T0 & $1.66 \pm 0.38$ & \multirow[t]{2}{*}{0.472} \\
\hline PD T1 & $1.55 \pm 0.45$ & \\
\hline CAL TO & $1.66 \pm 0.38$ & \multirow[t]{2}{*}{0.472} \\
\hline CAL T1 & $1.55 \pm 0.45$ & \\
\hline PI T0 & $1.15 \pm 0.74$ & \multirow[t]{2}{*}{0.216} \\
\hline PI T1 & $0.83 \pm 0.94$ & \\
\hline GI TO & $1.04 \pm 0.55$ & \multirow[t]{2}{*}{0.467} \\
\hline Gl T1 & $0.84 \pm 0.86$ & \\
\hline BOP TO & $42.85(0-100)$ & \multirow[t]{2}{*}{0.363} \\
\hline BOP T1 & $25.92(0-100)$ & \\
\hline TAC TO & $0.74 \pm 0.30$ & \multirow[t]{2}{*}{0.001} \\
\hline TAC T1 & $0.55 \pm 0.26$ & \\
\hline TOS TO & $14.65 \pm 9.10$ & \multirow[t]{2}{*}{0.969} \\
\hline TOS T1 & $14.77 \pm 11.29$ & \\
\hline OSI TO & $1.90 \pm 0.84$ & \multirow[t]{2}{*}{0.127} \\
\hline OSI T1 & $2.48 \pm 1.12$ & \\
\hline \multicolumn{3}{|c|}{$\begin{array}{l}\text { PD: Probing depth, CAL: Clinical attachment level, PI: Plaque index, GI: Gingival } \\
\text { index, BOP: Bleeding on probing, TAC: Total antioxidant capacity, TOS: Total oxidan } \\
\text { status, and OSI: Oxidative stress index, TO: Baseline before starting isotretinoin } \\
\text { treatment, T1: After six months, SD: Standard deviation }\end{array}$} \\
\hline
\end{tabular}

among the values of $\mathrm{BOP}, \mathrm{PI}$ and $\mathrm{GI}(\mathrm{p}<0.001)$ in the patient group. The TOS and OSI values were statistically different and they displayed positive correlations in both study groups $(p<0.05)$.

\section{Discussion}

The number of studies reporting about the association of isotretinoin treatment with $O S$ is limited in the literature ${ }^{8,21}$. The pathogenesis of the adverse effects observed with isotretinoin treatment is suggested to involve aggravated states of OS. OS leads to increased synthesis of ROS and elevated concentrations of ROS in the medium, contributing to aging and various diseases, including periodontal disease ${ }^{28}$

Saliva provides a medium to assess the antioxidant and oxidant activity in humans. The two key parameters that can be tested in the human saliva for this purpose are the TAC and TOS, demonstrating the cumulative activity of non-enzymatic activities of antioxidant and oxidant molecules present in the samples of saliva ${ }^{29}$. In our study, we evaluated the effect of isotretinoin on the periodontal tissues by evaluating the amounts of the salivary OS markers and the clinical periodontal parameters. The results of our study showed that; at the baseline, there were no differences in the initial PD, BOP, GI, PI TAC, TOS, and OSI values between the groups. This might have occurred because the individuals in the two study groups were in the same age range and, secondly, all individuals had only gingival problems but no advanced periodontal problems. Also, there were no significant differences in terms of clinical periodontal parameters such as $\mathrm{PD}, \mathrm{CAL}$, $\mathrm{Gl}, \mathrm{Pl}$, and BOP for test group in the sixth month compared to baseline. This can be explained by the fact that there was no change in the oral hygiene habits of the patients and no significant change in TOS levels of patients. Our results showed that isotretinoin did not have a significant effect on periodontal tissues that can be demonstrated by

Table 3. Correlations between the clinical periodontal parameters and salivary oxidative stress parameters in the study groups

\begin{tabular}{|c|c|c|c|c|c|c|c|c|c|c|c|c|c|}
\hline \multirow{2}{*}{\multicolumn{2}{|c|}{ Group }} & \multicolumn{2}{|l|}{ PI } & \multicolumn{2}{|l|}{ GI } & \multicolumn{2}{|l|}{ BOP } & \multicolumn{2}{|l|}{ TAC } & \multicolumn{2}{|l|}{ TOS } & \multicolumn{2}{|l|}{ OSI } \\
\hline & & \multicolumn{2}{|r|}{$p$} & \multicolumn{2}{|r|}{$n$} & $r$ & p & $r$ & $\mathbf{p}$ & $r$ & $p$ & $r$ & \multirow{2}{*}{$\begin{array}{l}\mathbf{p} \\
0.999\end{array}$} \\
\hline \multirow[t]{5}{*}{ Test } & $\mathrm{PD}(\mathrm{mm})$ & -0.075 & 0.789 & 0.191 & 0.495 & 0.252 & 0.364 & 0.421 & 0.118 & 0.272 & 0.326 & 000 & \\
\hline & $\mathrm{Gl}$ & $0.592^{*}$ & 0.020 & 1 & - & $0.878^{* *}$ & 000 & 0.148 & 0.599 & 0.213 & 0.447 & 0.096 & 0.734 \\
\hline & BOP & $0.744^{* *}$ & 0.001 & $0.878^{* *}$ & 0.000 & 1 & - & 0.147 & 0.601 & 0.197 & 0.482 & 0.111 & 0.693 \\
\hline & TOS & 0.035 & 0.902 & 0.213 & 0.447 & 0.197 & 0.482 & $0.697^{* *}$ & 0.004 & 1 & - & $0.795^{* *}$ & 000 \\
\hline & OSI & 0.082 & 0.770 & 0.096 & 0.734 & 0.111 & 0.693 & 0.160 & 0.569 & $0.795^{* *}$ & 000 & 1 & - \\
\hline \multirow[t]{4}{*}{ Control } & $\mathrm{PD}(\mathrm{mm})$ & 0.334 & 0.224 & 0.429 & 0.110 & 0.156 & 0.578 & -0.304 & 0.270 & -0.421 & 0.118 & -0.220 & 0.430 \\
\hline & PI & 1 & - & 0.302 & 0.274 & -0.033 & 0.908 & -0.312 & 0.257 & 0.151 & 0.591 & 0.444 & 0.097 \\
\hline & Gl & 0.302 & 0.274 & 1 & - & 0.431 & 0.109 & -0.494 & 0.061 & -0.052 & 0.853 & 0.305 & 0.268 \\
\hline & OSI & 0.444 & 0.097 & 0.305 & 0.268 & 0.262 & 0.346 & -0.469 & 0.078 & $0.632^{*}$ & 0.012 & 1 & - \\
\hline
\end{tabular}

r: Pearson correlation coefficient, ${ }^{*}$ Correlation is significant at the 0.05 level (2-tailed), ${ }^{*}$ Correlation is significant at the 0.01 level (2-tailed), PI: Plaque index. Gl: Gingival index, BOP: Bleeding on probing. PD: Probing depth, TAC: Total antioxidant capacity, TOS: Total oxidant status, OSI: Oxidative stress index 
clinical periodontal parameters. There are few studies investigating the effects of drugs on periodontal tissue in the literature. In a study using the clinical periodontal parameters as we used in our study, Mayer et al. ${ }^{30}$ evaluated the influence of anti-tumor necrosis factor-alpha (TNF-a) therapy on the clinical parameters of the periodontal tissues. While they found no difference between groups in terms of $\mathrm{Pl}$, they reported that patients with rheumatoid arthritis receiving anti-TNF-a medication had lower GI, PD, BOP and CAL values.

On the other hand, some researchers concluded that circulating concentrations of several antioxidants did not correlate with those in the oral and periodontal tissues ${ }^{31,32}$. Furthermore, Gümüş et al. ${ }^{33}$ found that neither smoking nor gingival inflammation affected the levels of glutathione, the ascorbic acid content, or the TAC in systemically healthy patients with gingivitis.

In our study; while the TAC and TOS values were not different between the groups at baseline, the TAC values were significantly reduced but the TOS values were not changed in the patient group in the $6^{\text {th }}$ month compared to the baseline. Conversely, Yorulmaz Demir et al. ${ }^{34}$ found out that serum TOS levels and OSI values of the patients elevated significantly but their TAC levels were not statistically different after the treatment compared to the values obtained before the treatment. Georgala et al. ${ }^{21}$ observed that serum TAC values were significantly lower in the acne vulgaris patients 45 days before the oral isotretinoin treatment administered at a dose of $0.5 \mathrm{mg} / \mathrm{kg} /$ day compared to the values obtained after the treatment and the values found in the control group. However, Ozkol et al. ${ }^{8}$ found out that the levels of TAC were reduced slightly after the isotretinoin treatment in alignment with our findings. The reasons for such discrepancies among the results of different studies may be related to several factors; including differences in obtaining or testing the saliva or serum samples, various periods of drug use, the different periodontal status of patients, and the number of patients included in studies.

Isotretinoin is commonly the treatment of choice to treat acne in adolescents and young adults ${ }^{35}$, who commonly need orthodontic treatment, orthognathic surgery, tooth extraction (extraction of the premolars or the third molars for orthodontic purposes), and periodontal treatment. Therefore, understanding the mechanism of action of the isotretinoin effects on oral tissue is critically important to achieving success in the treatment. Bergoli et al. ${ }^{36}$ conducted a preclinical study on rats to assess the effects of treatment with isotretinoin on the alveolar repair processes. They reported accelerations in the processes of alveolar tissue repair when isotretinoin was administered to the rats in daily doses corresponding to those used for the treatment of cystic acne in humans. Furthermore, Balcerzak et al. ${ }^{37}$ argued that retinoic acid promotes the mineralization processes possibly by increasing the fluidity of the osteoblast membrane and elevating the intracellular concentrations of calcium.

\section{Study Limitation}

One limitation of our study is the unavailability of antioxidant and bone biomarker values in serum and gingival crevicular fluid (GCF). However, the evaluation of such data was beyond the primary objective of our study since we primarily aimed to determine the antioxidant profile in the human saliva. Another limitation of our study is the small number of study patients. Although 25 participants were included in the study at baseline, 7 of them were lost to follow-up as they moved out of the city and discontinued the treatment.

\section{Conclusion}

The results of the current study may suggest that isotretinoin use for the treatment of acne vulgaris did not induce significant alterations in the periodontal tissues, except the significant reduction observed in the TAC levels. This finding may reflect impairment in the balance between the oxidant and antioxidant status. These alterations in the OS regulation may potentially take part in the pathological mechanisms involved in the emergence of isotretinoin's adverse effects. Further large-scale studies and assessment of oxidants in the serum and GCF of the patients would help to clarify the effects of isotretinoin on periodontal tissues.

\section{Ethics}

Ethics Committee Approval: This prospective study was conducted in the period from November 2017 to May 2018 after receiving the approval of the Clinical Research Ethics Committee of Bolu Abant Izzet Baysal University (approval number: 2017/85).

Informed Consent: Written informed consent was obtained from all participating patients.

Peer-review: Externally peer-reviewed.

\section{Authorship Contributions}

Surgical and Medical Practices: G.U., Ş.G., M.P., Concept: G.U., M.P., Design: G.U., M.P., Data Collection or Processing: G.U., Ş.G., M.P., Analysis or Interpretation: G.U., M.P., Literature Search: G.U., Ş.G., M.P., Writing: G.U., Ş.G., M.P.

Conflict of Interest: No conflict of interest was declared by the authors.

Financial Disclosure: The work was supported by the authors.

\section{References}

1. Rivera R, Guerra A: [Management of acne in women over 25 years of age]. Actas Dermosifiliogr 2009;100:33-7.

2. Elias PM: Epidermal effects of retinoids: supramolecular observations and clinical implications. J Am Acad Dermatol 1986;15:797-809.

3. Stern RS: Acne therapy. Medication use and sources of care in office-based practice. Arch Dermatol 1996;132:776-80.

4. Thielitz A, Krautheim A, Gollnick $H$ : Update in retinoid therapy of acne. Dermatol Ther 2006;19:272-9.

5. DiGiovanna JJ, Langman CB, Tschen EH, et al: Effect of a single course of isotretinoin therapy on bone mineral density in adolescent patients with severe, recalcitrant, nodular acne. J Am Acad Dermatol 2004;51:709-17.

6. Ling TC, Parkin G, Islam J, Seukeran DC, Cunliffe WJ: What is the cumulative effect of long-term, low-dose isotretinoin on the development of $\mathrm{DISH}$ ? $\mathrm{Br} J$ Dermatol 2001;144:630-2.

7. Pasquali MA, Gelain DP, de Oliveira MR, et al: Vitamin A supplementation for different periods alters oxidative parameters in lungs of rats. J Med Food 2009;12:1375-80

8. Ozkol HU, Ozkol H, Karadag AS, Bilgili SG, Tuluce Y, Calka O: Oral isotretinoin therapy of acne patients decreases serum paraoxonase-1 activity through increasing oxidative stress. Drug Chem Toxicol 2015;38:63-6.

9. Erturan I, Naziroglu M, Akkaya VB: Isotretinoin treatment induces oxidative toxicity in blood of patients with acne vulgaris: a clinical pilot study. Cell Biochem Funct 2012;30:552-7.

10. Avezov K, Reznick AZ, Aizenbud D: Oxidative stress in the oral cavity: sources and pathological outcomes. Respir Physiol Neurobiol 2015;209:91-4. 
11. Buonocore G, Perrone S, Tataranno ML: Oxygen toxicity: chemistry and biology of reactive oxygen species. Semin Fetal Neonatal Med 2010;15:186-90.

12. Al Moharib HS, Al Mubarak A, Al Rowis R, Geevarghese A, Preethanath RS, Anil S: Oral fluid based biomarkers in periodontal disease: part 1. Saliva. J Int Oral Health 2014;6:95-103.

13. Kamodyova N, Tothova L, Celec P: Salivary markers of oxidative stress and antioxidant status: influence of external factors. Dis Markers 2013;34:31321.

14. Chapple IL: Role of free radicals and antioxidants in the pathogenesis of the inflammatory periodontal diseases. Clin Mol Pathol 1996;49:M247-55.

15. Diab-Ladki R, Pellat B, Chahine R: Decrease in the total antioxidant activity of saliva in patients with periodontal diseases. Clin Oral Investig 2003;7:103-7.

16. Brock GR, Butterworth CJ, Matthews JB, Chapple IL: Local and systemic total antioxidant capacity in periodontitis and health. J Clin Periodonto 2004:31:515-21.

17. Baltacioglu E, Yuva P, Aydin G, et al: Lipid peroxidation levels and total oxidant/antioxidant status in serum and saliva from patients with chronic and aggressive periodontitis. Oxidative stress index: a new biomarker for periodontal disease? J Periodontol 2014;85:1432-41.

18. Brzezinski P, Borowska K, Chiriac A, Smigielski J: Adverse effects of isotretinoin: A large, retrospective review. Dermatol Ther 2017;30.

19. Fraunfelder FT, Fraunfelder FW, Edwards R. Ocular side effects possibly associated with isotretinoin usage. Am J Ophthalmol 2001;132:299-305.

20. Baykal Selcuk L, Aksu Arica D, Baykal Sahin H, Yayli S, Bahadir S: The prevalence of sacroilitis in patients with acne vulgaris using isotretinoin. Cutan Ocul Toxicol 2017;36:176-9.

21. Georgala S, Papassotiriou I, Georgala C, Demetriou E, Schulpis $\mathrm{KH}$ : Isotretinoin therapy induces DNA oxidative damage. Clin Chem Lab Med 2005;43:1178-82.

22. Loe $H$ : The gingival index, the plaque index and the retention index Systems J Periodontol 1967;38:Suppl:610-6.

23. Silness J, Loe H: Periodontal Disease in Pregnancy. li. Correlation between Oral Hygiene and Periodontal Condtion. Acta Odontol Scand 1964;22:121 35.

24. Erel O: A novel automated direct measurement method for total antioxidant capacity using a new generation, more stable ABTS radical cation. Clin Biochem 2004;37:277-85.
25. Erel O: A new automated colorimetric method for measuring total oxidant status. Clin Biochem 2005;38:1103-11.

26. Yumru M, Savas HA, Kalenderoglu A, Bulut M, Celik H, Erel O: Oxidative imbalance in bipolar disorder subtypes: a comparative study. Prog Neuropsychopharmacol Biol Psychiatry 2009;33:1070-4

27. Kosecik M, Erel O, Sevinc E, Selek S: Increased oxidative stress in children exposed to passive smoking. Int I Cardiol 2005;100:61-4.

28. Wang $Y$, Andrukhov O, Rausch-Fan $X$ : Oxidative stress and antioxidant system in periodontitis. Front Physiol 2017;8:910.

29. Kinney JS, Morelli T, Braun T, et al: Saliva/pathogen biomarker signatures and periodontal disease progression. J Dent Res 2011;90:752-8.

30. Mayer Y, Balbir-Gurman A, Machtei EE: Anti-tumor necrosis factor-alpha therapy and periodontal parameters in patients with rheumatoid arthritis. J Periodontol 2009;80:1414-20.

31. Moore S, Calder KA, Miller NJ, Rice-Evans CA: Antioxidant activity of saliva and periodontal disease. Free Radic Res 1994;21:417-25.

32. Cowan CG, Calwell El, Young IS, McKillop DJ, Lamey PJ: Antioxidant status of oral mucosal tissue and plasma levels in smokers and non-smokers. J Oral Pathol Med 1999;28:360-3.

33. Gümüş P, Buduneli N, Cetinkalp S, et al: Salivary antioxidants in patients with type 1 or 2 diabetes and inflammatory periodontal disease: a case-control study. J Periodontol 2009;80:1440-6.

34. Yorulmaz Demir A, Metin A, Işıkoğlu S, Erel Ö: The effect of isotretinoin on oxidative stress in severe acne vulgaris patients. Turkiye Klinikleri J Med Sci 2012;32:1026-31.

35. Erdogan BS, Yuksel D, Aktan S, Ergin S, Kirac FS: The effects of isotretinoin treatment on bone mineral density in patients with nodulocystic acne. J Eur Acad Dermatol Venereol 2006;20:1006-7.

36. Bergoli RD, Chagas Junior $\mathrm{OL}$, de Souza $C E$, et al: Isotretinoin effect on alveolar repair after exodontia-a study in rats. Oral Maxillofac Surg 2011;15:85-92.

37. Balcerzak M, Hamade E, Zhang L, et al: The roles of annexins and alkaline phosphatase in mineralization process. Acta Biochim Pol 2003;50:1019-38. 